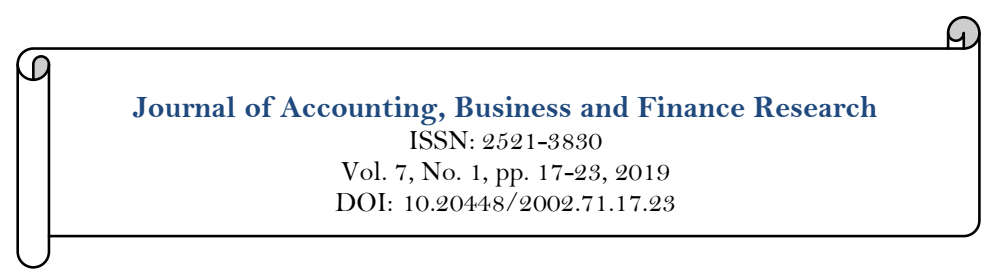

\title{
Executive Social Network and Enterprise Innovation
}

\author{
Juan Zhang \\ School of Economics, Central University of Financial and Economics, Beijing, P.R. China. \\ Email:julia0313@163.com
}

\section{Abstract}

This paper tests the impact of executive social network on enterprise innovation, and analyzes the impact of executive social network on the innovation of target enterprises and connected enterprises. Through empirical research, we find that the executive social network significantly promotes enterprise innovation, indicating that the available resources embedded in the executive social network have played their roles. In addition, based on the organizational learning theory and Mosaic theory, this paper finds that the innovation level of enterprises with executive social network has been significantly improved. Furthermore, when the sample is divided into target companies and connected companies, the empirical results show that the innovation level of connected companies is significantly improved. Through communication and successful experience exchange, the innovation level of connected enterprises is improved.

Keywords:

Executive social network

Innovation

Connection

Licensed:

This work is licensed under a

Creative Commons Attribution 4.0

License.

Publisher:

Scientific Publishing Institute

Accepted: 13 August 2019

Published: 26 August 2019

Funding: This study received no specific financial support.

Competing Interests: The author declares that there are no conflicts of interests regarding the publication of this paper.

\section{Introduction}

Enterprise innovation, as the source power of enterprise development, is also an important aspect of enterprise core competitiveness. Therefore, enterprise innovation has become a hot topic in recent years, especially the research on improving the level of enterprise innovation. Through research, it is found that about $85 \%$ of the listed companies in China have the director network. As one of the important relationships among enterprises, board network (inter-locking directorates and executive connections) has increasingly farreaching influence on enterprises. However, research on the influence of director network on enterprise innovation is relatively little. According to previous studies by scholars, executive social network is embedded with a lot of social capital and resources, which can provide enterprises with efficient and convenient channels for communication and information exchange.

\section{Literature Review and Research Hypothesis}

Lin (2001) pointed out that social capital is obtained through the relationships of social network of actors, and it plays its role by utilizing the connections and resources in its network or group. In combination with the mosaic theory proposed by Granovetter (1985) social capital is embedded in the executive social relationship network, that is, the important information and resources related to operation and governance that are needed by enterprises.

Executive social network is an important connection among enterprises, and its communication and information transmission have an impact on all aspects of enterprises. Senior executives working in many an enterprise play a certain positive role in promoting enterprise innovation. Studies carried out by Dalziel, Santucci, and Spedo (2011) indicate that inter-locking board, as the media of knowledge and information 
communication for external environment of enterprises, can make them obtain more information on $\mathrm{R} \& \mathrm{D}$ decision-making, feasibility of implementation and potential alternatives, which can help produce more scientific and reasonable demonstrations on making R\&D investment decisions, improving the efficiency of R\&D investment decision-making. Duan (2012) found that inter-locking board can help improve the innovation performance of enterprises and reduce organizational slack. However, reduction of organizational slack cannot improve the innovation performance of enterprises. Fan and Duan (2016) pointed out that the social capital of board network promotes the efficiency of enterprises' r\&d investment decision making, and thus improves the innovation level of enterprises. Yan and Hua (2017) found through research that the centrality of inter-locking board network and the richness of structural holes significantly promote enterprise innovation. Wang and Zhang (2018) studied the board network and enterprise innovative decision of private enterprises and found that attracting capital and wisdom through board network promotes the innovation level of enterprises. They held that private enterprises in China could improve their innovation level through the establishment of board network. Liu (2018) pointed out that the higher centrality of the board network is, the more beneficial it is to formulation and implementation of the progressive innovation strategy, which reduces the uncertainty of risks and returns, enhances the confidence of creditors and management, and thus enables enterprises to collect funds from creditors; in addition, repetitive and redundant information is not conducive to enterprises' breakthrough innovation activities as they has higher centrality in the board network, which thus makes enterprises adopt conservative financial strategies to maintain a lower financial leverage.

According to the theory of organizational learning, enterprises can learn in two ways: one is selfexperience learning, and the other is alternative learning (obtained from other enterprises). Learning through self-experience often requires constant repetition and error correction, which needs a large amount of resources and a high cost. Especially when enterprises have insufficient experience and uncertain behaviour results, it is difficult for enterprises to comprehensively observe their own response, leading enterprises to make wrong judgment based on previous experience. Enterprise innovation is an investment with comparatively high risks, and manpower and capital costs invested by enterprises may not achieve corresponding returns in the end. Therefore, improving the enterprise innovation level is a challenge. Some scholars believe that improvement of the motivation level can help make decisions on promoting enterprise innovation level; alleviating financing constraints faced by enterprises and establishing political connections can help improve enterprise innovation level.

Hypothesis 1: The executive social network among enterprises can significantly improve enterprise innovation level.

Alternative learning efficiency based on the theory of organizational learning can become higher. Enterprises acquire corresponding knowledge from the outside and ultimately transform it into knowledge that enterprises can make use of through their own absorption and understanding. Executive social network is one of the important channels for enterprises to learn from each other. Through the network, enterprises improve valid information acquisition efficiency and learning efficiency among enterprises. Then, for enterprise innovation, experience of successful innovation projects can be conveyed among enterprises through the executive social network, so as to improve the innovation efficiency of enterprises. Experience of enterprise innovation failure can also be transmitted among connected enterprises, which can help enterprises avoid relevant risks and improve the innovation efficiency of enterprises. Successful experience of enterprises in the executive social network, especially those with high innovation level, can become the learning content for other connected enterprises in the network. Through communication and exchange, the innovation level of connected enterprises can be improved. Based on the above analysis, we propose hypothesis 2 of this paper:

Hypothesis 2: Enterprises that form a connection with those of a high level of innovation have a significant improvement in their innovation level.

\section{Research Design}

3.1. Research Samples and Data Sources

This paper selects the data of Shanghai and Shenzhen A-share listed enterprises from 2002 to 2014 as samples, which come from CSMAR database, WIND database and Sina Finance and Economics network. The specific sources are as follows: personal information of senior executives (including positions, resumes, etc.) comes from CSMAR, and relevant missing data are supplemented from Sina Finance and Economics network; part of enterprises' financial data and related patent application data come from CSMAR, while the rest come from WIND. After excluding enterprise data of the financial industry and missing data of the senior executives, the number of samples of the executive social network at the executive level is 56,148 , and the number of samples size at the enterprise level is 19,212. In order to avoid influence from outliers on the research results, the relevant data in this paper are winsorized by $1 \%$.

The handling process of the data of executive social network is as follows: this paper collects the basic information of senior executives of listed enterprises (including information about their positions, resumes and personal introductions, etc.) from CSMAR, and relevant missing data are manually supplemented and completed from Sina Finance and Economics network; in the data handling process, it is necessary to manually 
remove repeated names and surnames of senior executives in order to obtain the real data of executive social network.

\subsection{Variable Definition}

\subsubsection{Executive Social Network}

In this paper, the executive social network is defined as the relationship network formed by senior executives (directors, supervisors, general managers, financial directors and other senior management) of a company who concurrently hold management positions (such as directors, supervisors and other management positions) in other companies. Drawing on the methods of scholars at home and abroad (Stuart \& Yim, 2010; Zhang, 2014) this paper measures the executive social network variables as follows: when executives of company A hold concurrent executive positions in company B, the executive social network (Interlock) is valued as 1 , indicating that $\mathrm{A}$ and $\mathrm{B}$ are connected to each other; when executives of company $\mathrm{A}$ do not own positions in other companies, the executive social network (Interlock) is valued as o, indicating that there is no connection between Company A and other companies.

\subsubsection{Enterprise Innovation}

This paper uses the natural logarithm of the sum of the number of enterprise patent applications (including patents, inventions and design patents) and 1 as the proxy variable of enterprise innovation (Pan \& Zhang, 2016). Since patent application and authorization of enterprises have the characteristic of lag, the patents applied or authorized do not indicate that they are the achievements of that year, but may be the results of previous years. Therefore, in the robustness test, this paper sets lag 1 and 2 data of innovation, which are respectively analyzed in the empirical test model (Pan \& Zhang, 2016; Yao \& Zhou, 2018). At the same time, this paper takes the total number of patents as the proxy variable of enterprise innovation.

\subsubsection{Control Variable}

Drawing on the previous studies of scholars (Li \& Song, 2010; Pan \& Zhang, 2016) this paper controls other factors that may affect enterprise innovation in the model, including enterprise size, financial leverage, return on assets, shareholding ratio of major shareholders, loss, enterprise nature, enterprise age, etc. The detail information of the variable definitions is stated in the Table 1.

\begin{tabular}{|c|c|c|}
\hline Variable Name & Code & Definition \\
\hline \multirow[t]{2}{*}{$\begin{array}{l}\text { Enterprise } \\
\text { innovation }\end{array}$} & Lnpatent & $\begin{array}{l}\text { The natural logarithm of the sum of the number of } \\
\text { enterprise patent applications (including patents, } \\
\text { inventions and design patents) and } 1 \text { in year t. }\end{array}$ \\
\hline & Patent & $\begin{array}{l}\text { The sum of the number of enterprise patent applications } \\
\text { including patents, inventions and design patents in year t. }\end{array}$ \\
\hline $\begin{array}{l}\text { Executive social } \\
\text { network }\end{array}$ & Interlock & $\begin{array}{l}\text { Dummy variable, when there is the social network between } \\
\text { the managements, the value should be } 1 \text {, and otherwise the } \\
\text { value should be } 0 \text {, means there are not the connections. }\end{array}$ \\
\hline $\begin{array}{l}\text { Corporate } \\
\text { performance }\end{array}$ & $\mathrm{ROA}$ & The ROA in $\mathrm{t}$ year, the net profit / the total assets. \\
\hline Outside director ratio & $\begin{array}{l}\text { OUTSIDE_DIR } \\
\text { ECTOR }\end{array}$ & The ratio of independent director of the boards in $\mathrm{t}$ year. \\
\hline $\begin{array}{l}\text { proportion of the } \\
\text { largest shareholder }\end{array}$ & BLOCK & Proportion of the largest shareholder in $t$ year. \\
\hline $\begin{array}{l}\text { Management } \\
\text { payment }\end{array}$ & M_PAY & $\begin{array}{l}\text { The natural logarithm of the payments of management in } t \\
\text { year. }\end{array}$ \\
\hline $\begin{array}{l}\text { Shareholding rate of } \\
\text { management }\end{array}$ & M_SHARE & The proportion of the management shareholding in $\mathrm{t}$ year. \\
\hline Corporate nature & STATE & $\begin{array}{l}\text { Dummy variable, the nature of the enterprise at the end of } t \\
\text { is state-owned enterprise, value is } 1 \text {, otherwise value is } 0\end{array}$ \\
\hline Corporate scale & SIZE & The natural logarithm of the value of the assets in $t$ year. \\
\hline Corporate leverage & LEV & $\begin{array}{l}\text { The leverage of the corporate, the total liability/total } \\
\text { assets in } t \text { year. }\end{array}$ \\
\hline Loss & LOSS & $\begin{array}{l}\text { Dummy variable, the net profit is less than } 0 \text {, the value is } 1 \text {; } \\
\text { the net profit is more than } 0 \text {, the value is } 0 \text {. }\end{array}$ \\
\hline Corporate age & AGE & The number of years the corporate has been listed. \\
\hline
\end{tabular}

\subsection{Model Construction}

In this paper, the current data of enterprises are used for testing the influence of executive social network on enterprise innovation through the following model. Since enterprise innovation has a certain lag, the above 
factors are taken into account in the robustness test model in this paper. Explanatory variables are tested by data of lag 1 and lag 2 respectively.

Lnpatent $_{i, t}$ / Patent $_{i, t}=\alpha_{0}+\alpha_{1}$ Interlock $_{i, t}+\alpha_{2}$ SIZE $_{i, t}+\alpha_{3}$ ROA $_{i, t}+\alpha_{4}$ LOSS $_{i, t}+\alpha_{5}$ LEV $_{i, t}+\alpha_{6}$ STATE $_{i, t}+\alpha_{7}$ BLOCK $_{i, t}$

$$
+\alpha_{8} \text { OUTSIDE_DIRECTOR } \text { I }_{i, t}+\alpha_{9} M_{-} \text {SHARE }_{i, t}+\alpha_{10} M_{-} P A Y_{i, t}+\alpha_{11} A G E_{i, t}+\varepsilon_{i, t}
$$

Control variables involved in the model referring to previous studies by scholars (Li \& Song, 2010) take other factors that may affect enterprise innovation into consideration.

\section{Analysis of Empirical Research Results}

\subsection{Descriptive Statistics}

Descriptive statistical results of various variables are reported in Table 4-2 indicating that the average number of patents applied by sample enterprises is 59, among which the maximum number of applications is 2066 and the minimum number is O. Interlock's results show that $89.69 \%$ of listed companies have executive social network on average.

Table-2. Descriptive statistics.

\begin{tabular}{c|c|c|c|c|c}
\hline Variables & $\mathbf{N}$ & Max & Min & Mean & Median \\
\hline Patent & 17969 & 1492 & 2 & 77.71139 & 20 \\
\hline Lnpatent & 17969 & 7.308543 & 1.098612 & 3.129054 & 3.044523 \\
\hline Interlock & 17969 & 1 & 0 & .9619344 & 1 \\
\hline SIZE & 17969 & 25.48062 & 18.62254 & 21.92341 & 21.7126 \\
\hline LEV & 17969 & 1.462868 & .0644525 & .4474501 & .4536224 \\
\hline LOSS & 17969 & 1 & 0 & .078858 & 0 \\
\hline BLOCK & 17969 & 77.83 & 9.03 & 36.98176 & 35.43 \\
\hline ROA & 17969 & .2676835 & -.2894406 & .044173 & .0409215 \\
\hline STATE & 17969 & 1 & 0 & .4987478 & 0 \\
\hline Outsiede_Director & 17969 & .5454546 & .0666667 & .3549715 & .3333333 \\
\hline BLOCK & 17969 & 77.83 & 9.03 & 36.98176 & 35.43 \\
\hline M_SHARE & 17969 & $5.43 \mathrm{e}-06$ & 0 & $6.66 \mathrm{e}-08$ & 0 \\
\hline AGE & 17969 & 2762050 & 3802435 & 297000 & $2.19 \mathrm{E}+07$ \\
\hline
\end{tabular}

\subsection{The Correlation Analysis}

The correlation coefficients of the main variables are reported in Table 3; the result shows that there is a significant positive correlation between enterprise innovation and executive social relation network at the level of $1 \%$. This indicates that executive social network has a significant impact on enterprise innovation, supporting hypothesis 1 .

Table-3. The correlations of the main variables

\begin{tabular}{c|c|c|c}
\hline Variables & lnpatent & Patent & Interlock \\
\hline Inpatent & 1.000 & $0.650^{* * *}$ & $0.043^{* * *}$ \\
\hline Patent & $0.903^{* * *}$ & 1.000 & $0.073^{* * *}$ \\
\hline Interlock & $0.044^{* * *}$ & $0.061^{* * *}$ & 1.000 \\
\hline
\end{tabular}

Note: $* * *, * *$ and $*$ are significant at the levels of $1 \%, 5 \%$ and $10 \%$ respectively, with Pearson correlation coefficient at the lower left corner and Spearman correlation coefficient at the upper right corner.

\subsection{Univariate Difference Analysis}

The results of Panel $\mathrm{A}$ in Table 4 are $\mathrm{T}$ test and $\mathrm{Z}$ test respectively for the mean values of innovation of enterprises with and without executive social network. Significant differences were found between them. It shows that executive social network has a significant impact on enterprise innovation. The result of Panel B indicates that the average value of enterprise innovation between companies with high innovation level and connected companies is tested by $\mathrm{T}$ test and $\mathrm{Z}$ test; we found the significant difference between them.

\subsection{Empirical Test}

4.4.1. Executive Social Network and Enterprise Innovation

Table 5 is the empirical research results of executive social network and enterprise innovation after controlling the characteristics of enterprises (SIZE,ROA,LEV,LOSS) and enterprise governance characteristics (BLOCK, OUTSIDE_DIRECTOR, M_SHARE) that may affect enterprise innovation level. According to the data in the table, there is a correlation between Interlock and Lnpatent. Interlock has significantly positive correlation with Lnpatent at the $1 \%$ level (0.358***, 7.09); Interlock has a significant positive correlation with Patent at $10 \%$ level $\left(10.839^{*}, 1.85\right)$. The above results show that enterprises can obtain various social capital embedded in the executive social network through communication and 
information acquisition functions of the network, such as the successful experience of improving enterprise innovation level, which can significantly promote the improvement of enterprise innovation level, supporting hypothesis 1 .

Table-4. Univariate difference analysis.

\begin{tabular}{|c|c|c|c|c|c|c|c|}
\hline \multirow{2}{*}{\multicolumn{2}{|c|}{ Variable }} & \multicolumn{2}{|c|}{$\begin{array}{c}\text { Without executive } \\
\text { social networks }\end{array}$} & \multicolumn{2}{|c|}{$\begin{array}{l}\text { With executive } \\
\text { social networks }\end{array}$} & \multirow[t]{2}{*}{ T test } & \multirow[t]{2}{*}{$\mathrm{Z}$ test } \\
\hline & & Mean & $\begin{array}{l}\text { Standard } \\
\text { deviation }\end{array}$ & Mean & $\begin{array}{l}\text { Standard } \\
\text { deviation }\end{array}$ & & \\
\hline \multicolumn{8}{|l|}{ Panel A } \\
\hline \multirow{2}{*}{$\begin{array}{l}\text { Corporate } \\
\text { innovation }\end{array}$} & Lnpatent & 2.712 & 1.112 & 3.208 & 1.400 & $-12.076^{* * * *}$ & $-9.4411^{*} * *$ \\
\hline & Patent & 29.752 & 75.092 & 84.097 & 244.720 & $-18.355^{* * * *}$ & $-9.441 * * *$ \\
\hline \multicolumn{8}{|l|}{ Panel B } \\
\hline \multirow{4}{*}{$\begin{array}{l}\text { Corporate } \\
\text { innovation }\end{array}$} & & \multicolumn{2}{|c|}{ Target Company } & \multicolumn{2}{|c|}{ Connection Company } & T test & $Z$ test \\
\hline & & Mean & $\begin{array}{l}\text { Standard } \\
\text { deviation }\end{array}$ & Mean & $\begin{array}{l}\text { Standard } \\
\text { deviation }\end{array}$ & & \\
\hline & Lnpatent & 3.024 & 1.032 & 2.450 & 1.307 & $-10.137^{* * * *}$ & $-8.166^{* * * *}$ \\
\hline & Patent & 58.597 & 157.849 & 20.461 & 35.948 & $-14.131 * * *$ & $-8.166^{* * * *}$ \\
\hline
\end{tabular}

Table-5. The executive social network and innovation.

\begin{tabular}{|c|c|c|}
\hline & $(1)$ & $(2)$ \\
\hline Variables & Lnpatent & Patent \\
\hline \multirow[t]{2}{*}{ Interlock } & $0.358^{* * *}$ & $10.839^{*}$ \\
\hline & $(7.09)$ & $(1.85)$ \\
\hline \multirow[t]{2}{*}{$\mathrm{SIZE}$} & $0.000^{* * *}$ & $0.000^{* * *}$ \\
\hline & $(14.06)$ & $(30.52)$ \\
\hline \multirow[t]{2}{*}{$\mathrm{ROA}$} & $1.061^{* * *}$ & $-101.223^{* *}$ \\
\hline & $(2.87)$ & $(-2.36)$ \\
\hline \multirow[t]{2}{*}{ LOSS } & -0.085 & $-30.040 * * *$ \\
\hline & $(-1.20)$ & $(-3.67)$ \\
\hline \multirow[t]{2}{*}{ LEV } & $0.642^{* * *}$ & $43.857^{* * *}$ \\
\hline & $(6.86)$ & $(4.03)$ \\
\hline \multirow[t]{2}{*}{ STATE } & $-0.080^{* * *}$ & -0.641 \\
\hline & $(-2.10)$ & $(-0.14)$ \\
\hline \multirow[t]{2}{*}{ BLOCK } & $0.005^{* * *}$ & -0.112 \\
\hline & $(4.80)$ & $(-0.91)$ \\
\hline \multirow[t]{2}{*}{ OUTSIDE_DIRECTOR } & $1.963^{* * *}$ & $-56.12 \mathrm{O}^{* *}$ \\
\hline & $(9.72)$ & $(-2.39)$ \\
\hline \multirow[t]{2}{*}{ M_SHARE } & $-61,596.287^{* *}$ & -3491890.475 \\
\hline & $(-2.33)$ & $(-1.14)$ \\
\hline \multirow[t]{2}{*}{ M_PAY } & $0.000^{* * * *}$ & $0.000^{* * *} *$ \\
\hline & $(18.63)$ & $(19.21)$ \\
\hline \multirow[t]{2}{*}{$\mathrm{AGE}$} & 0.001 & -0.025 \\
\hline & $(0.16)$ & $(-0.06)$ \\
\hline Observations & 6,428 & 6,428 \\
\hline R-squared & 0.863 & 0.329 \\
\hline p-value & $\mathrm{O}$ & $\mathrm{O}$ \\
\hline
\end{tabular}

\subsubsection{Further Analysis}

The empirical test results in Table 6 show the organizational learning effect of companies with executive social network, that is, whether the formation of network with companies of high innovation level improves the innovation level of connected companies or not. As can be seen from the data in the table, the target company, as a company of high innovation level, has significantly improved its innovation level after the establishment of social network (0.381***, 12.282**); the innovation level of connected companies has been significantly improved after establishing the social network with target companies, as shown by the correlation coefficient between Lnpatent and Interlock (1.323***,2.80); the correlation coefficient between Patent and Interlock is $\left(13.715^{*}, 1.91\right)$. The results support hypothesis 2 . According to the theory of organizational learning, the successful experience of enterprises in executive social network, especially those of high innovation level, can become the learning content of other connected enterprises in the network. Through communication and exchange, the innovation level of connected enterprises is improved. 
Table-6. The executive social network and innovation (Target Company vs. Connection Company).

\begin{tabular}{|c|c|c|c|c|}
\hline & $(1)$ & $(2)$ & $(3)$ & $(4)$ \\
\hline Variables & Lnpatent(TC) & Lnpatent(CC) & Patent(TC) & Patent(CC) \\
\hline \multirow[t]{2}{*}{ Interlock } & $0.381 * * *$ & $1.323 * * *$ & $12.282^{* *}$ & $13.715^{*}$ \\
\hline & $(7.48)$ & $(2.80)$ & $(2.03)$ & $(1.91)$ \\
\hline \multirow[t]{2}{*}{ SIZE } & 0.000**** & 0.000 & $0.000^{*} * *$ & 0.000 \\
\hline & $(13.78)$ & $(0.92)$ & $(29.70)$ & $(0.20)$ \\
\hline \multirow[t]{2}{*}{$\mathrm{ROA}$} & $1.051 * * *$ & 0.658 & $-101.057 * *$ & -23.417 \\
\hline & $(2.76)$ & $(0.44)$ & $(-2.24)$ & $(-0.44)$ \\
\hline \multirow[t]{2}{*}{ LOSS } & -0.095 & 0.038 & $-31.650^{* * * *}$ & -6.451 \\
\hline & $(-1.31)$ & $(0.14)$ & $(-3.68)$ & $(-0.67)$ \\
\hline \multirow[t]{2}{*}{ LEV } & $0.696 * * *$ & -0.099 & $50.147 * * *$ & -6.159 \\
\hline & $(7.20)$ & $(-0.28)$ & $(4.38)$ & $(-0.49)$ \\
\hline \multirow[t]{2}{*}{ STATE } & -0.064 & $-0.292^{* *}$ & -0.097 & -5.276 \\
\hline & $(-1.63)$ & $(-2.00)$ & $(-0.02)$ & $(-1.01)$ \\
\hline \multirow[t]{2}{*}{ BLOCK } & $0.005^{* * *} *$ & 0.002 & -0.110 & -0.148 \\
\hline & $(4.63)$ & $(0.49)$ & $(-0.85)$ & $(-0.99)$ \\
\hline \multirow[t]{2}{*}{ OUTSIDE_DIRECTOR } & $1.977^{* * * *}$ & 0.779 & $-61.474^{* * *}$ & 14.450 \\
\hline & $(9.53)$ & $(0.90)$ & $(-2.50)$ & $(0.46)$ \\
\hline \multirow[t]{2}{*}{ M_SHARE } & $-60,142.878^{* * *}$ & $-43,844.555$ & -3773479.124 & $-504,124.566$ \\
\hline & $(-2.19)$ & $(-0.49)$ & $(-1.16)$ & $(-0.16)$ \\
\hline \multirow[t]{2}{*}{ M_PAY } & $0.000^{*} * *$ & $0.000^{*} *$ & $0.000 * * *$ & $0.000^{*} *$ \\
\hline & $(18.64)$ & $(2.39)$ & $(19.22)$ & $(2.20)$ \\
\hline \multirow[t]{2}{*}{$\mathrm{AGE}$} & -0.002 & 0.006 & -0.150 & 0.080 \\
\hline & $(-0.53)$ & $(0.42)$ & $(-0.34)$ & $(0.16)$ \\
\hline Observations & 6,090 & 338 & 6,090 & 338 \\
\hline R-squared & 0.865 & 0.857 & 0.335 & 0.271 \\
\hline p-value & $\mathrm{O}$ & $\mathrm{O}$ & & \\
\hline
\end{tabular}

\section{Brief Summary}

Based on the data of listed companies from 2002 to 2014, this paper tests the impact of executive social relationship network on enterprise innovation, and analyzes the impact of executive social network on the innovation of target enterprises and connected enterprises. Through empirical research, we find that the executive social network significantly promotes enterprise innovation, indicating that the available resources embedded in the executive social network have played their roles. In addition, based on the organizational learning theory and Mosaic theory, this paper finds through empirical research that the innovation level of enterprises with executive social network has been significantly improved. In addition, when the samples are divided into target companies and connected companies, the empirical results show that the innovation level of connected companies is significantly improved. Successful experience of enterprises in executive social network, especially those of high innovation level, can become the learning content of other connected enterprises in the network. Through communication and exchange, the innovation level of connected enterprises is improved.

\section{References}

Dalziel, F., Santucci, A., \& Spedo, G. (2011). Rewriting the 'Duchess of Malfi': Adapting Webster's tragedy for an ESL drama production. Scenario, 1, 5-20.

Duan, H. (2012). Research on the relationship between organizational redundancy and enterprise innovation performance. Science of Science, 30(4), 631-640.

Fan, L., \& Duan, H. (2016). Review of research on chain directors, corporate governance and enterprise technology innovation. Cooperative Economy and Technology, 5, 88-91.

Granovetter, M. (1985). Economic action and social structure: The problem of embeddedness. American Journal of Sociology, 91(3), 481-510.

Li, C., \& Song, M. (2010). Innovation activities of Chinese manufacturing enterprises: Ownership and the role of CEO incentives. Xinhua Digest, 15, 135-137.

Lin, N. (2001). Karen S. Cook, and Ronald S. Burt, eds. Social capital: Theory and research: Transaction Publishers.

Liu, Y. (2018). Director network location, enterprise innovation strategy and financing structure -- empirical test based on innovation type. Friends of Accounting, $20,7$.

Pan, H., \& Zhang, R. (2016). Does political association of independent directors contribute to innovation of private enterprises? Journal of Zhengzhou Institute of Aeronautical Industry Management, 2, 63-75.

Stuart, T. E., \& Yim, S. (2010). Board interlocks and the propensity to be targeted in private equity transactions. Journal of Financial Economics, 97(1), 174-189. 
Wang, Y., \& Zhang, G. (2018). Director network and enterprise innovation: Attracting capital and wisdom. Financial Research, 456(6), 189-206.

Yan, R., \& Hua, X. (2017). Environmental uncertainty, chain director network location and enterprise innovation investment. Journal of Management, 14(3), 373- 390

Yao, L., \& Zhou, Y. (2018). Management ability, innovation level and innovation efficiency. Accounting Research, 6, $70-77$.

Zhang, R. (2014). Inter-firm executive connection and accounting information quality: Research perspective based on inter-firm network relationship. Accounting Research, 4, 27-33. 